A.Yu. Zhuravlov, A.V. Shijan, B.M. Shirokov

\title{
GAS-PHASE DEPOSITION OF CAVITATION-RESISTANT COATINGS BASED ON BORON CARBIDE
}

\author{
National Science Center "Kharkov Institute of Physics and Technology» \\ 1 Akademicheskaya Str., Kharkov, 61108,Ukraine,E-mail: shirokov@kipt.kharkov.ua
}

\begin{abstract}
Reliability and profitability of NPP operation of any type to a large extent depend on the reliable operation of the system of its pipelines. From literary sources is shown that the most dangerous zone, in terms of erosion wear, is a pipeline fluctuation. Solving the problem of erosion wear of the zone of the twists of the pipelines is possible by gas phase depositing protective coatings based on boron carbide, which slow down the cavitation processes of wear. This paper presents the results of studies on the production of a cavitation-resistant coating based on boron carbide by hydrogen reduction of boron trichloride $\mathrm{BCl}_{3}$ and toluene $\mathrm{C}_{7} \mathrm{H}_{8}$. Boron carbide was carried out on a plant with a horizontal flow-type reaction chamber. The principle of its operation consists in passing through the reaction chamber of the vapor-gas flow of reagents entering the chemical reaction on the surface of the heated substrate located inside the reaction chamber. Solid phase reaction products form an increasing condensate layer on the substrate surface and gaseous products are removed from the reaction chamber and neutralized. Trichloride boron $\mathrm{BCl}_{3}$ and toluene $\mathrm{C}_{7} \mathrm{H}_{8}$ were selected as reagents. Carrying gas and activator was hydrogen $\mathrm{H}_{2}$. Deposition was carried out on the austenitic steel substrate. It was shown that morphology of the surface is characterized by grapple-scraped globules. X-ray spectral studies have shown that the distribution of elements is uniform, this indicates that when austenitic steel is heated, no significant changes in properties occur. Diffractometric studies have shown that coating contains grain of $\mathrm{Fe}_{2} \mathrm{~B}$ iron boride and $\mathrm{Fe}_{7} \mathrm{C}_{3}$ iron carbide. measurement microhardness have shown that from the center of the substrate to the side of the coating is increased in double. Destruction of samples under the influence of cavitation was studied on the installation of ultrasound cavitation. The cavitation zone was formed between the end of the emitter, which is connected with an ultrasonic generator of UZG-3 0.4 type, and the surface of the test specimen installed in water having the temperature of $293 \mathrm{~K}$. For comparison, the kinetic curve of the destruction of the standard A18H10T austenitic steel and a boron carbide-based sample is given. Under the same test conditions, the nature of the kinetic curves is different. A sample with a carbide-borne coating is 2.5 times less cavitation wear than austenitic steel.
\end{abstract}

Keywords: gas-phase precipitation, boron carbide, cavitation wear

\section{INTRODUCTION}

Reliability and profitability of NPP operation of any type to a large extent depend on the reliable operation of the system of its pipelines. The total mass of NPP pipelines is $12-15 \%$ of the total mass of mechanical equipment of the station, which emphasizes the importance of studying the physical processes that occur in them. From the literature data, for the most part, the work is devoted to the modeling of the control of erosion wear of the twists of the steam generators pipelines. In [2] the thickness of erosion wear of the pipeline wall is calculated and it is shown that erosion wear occurs in the pipeline's spin zone. In work [3] the results of calculations of trajectories of motion of particles of different diameters at collision rates of droplets with the wall of the pipeline are given. Calculations have shown that the most dangerous zone, in terms of erosion wear, is a pipeline fluctuation. Consequently, cavitation wear is formed on the inner surface of the pipeline turns due to the mechanical impact of the cavitation flow with the material of the pipeline. This leads to serious localized destruction of structural materials.

Solving the problem of erosion wear of the zone of the twists of the pipelines is possible by depositing protective coatings based on boron carbide, which slow down the cavitation processes of wear. Boron carbide has a high melting point, high hardness, mechanical properties, low specific gravity, high resistance to the influence of chemical agents, therefore this material is promising for protecting the surface of pipelines from cavitation wear.

\section{METHOD OF EXPERIMENT}

Boron carbide was prepared on a plant with a horizontal flow-type reaction chamber. The 
principle of its operation consists in passing through the reaction chamber of the vapor-gas flow of reagents entering the chemical reaction on the surface of heated substrate located inside the reaction chamber. Solid phase reaction products form an increasing condensate layer on the substrate surface and gaseous products are removed from the reaction chamber and neutralized. The thrichloride boron $\mathrm{BCl}_{3}$ and toluene $\mathrm{C}_{7} \mathrm{H}_{8}$ were selected as reagents. Carrying gas and activator was hydrogen $\mathrm{H}_{2}$. Deposition was carried out on the austenitic steel substrate.

While depositing boron carbide coatings, it is important not only to keep the precipitated layer uniform, but also observe constancy of the condensate composition on the surface coated. In the CVD techniques, these requirements depend on the temperature field uniformity on the coated surface and vapor-gas mixture gas-dynamic parameters throughout the reaction volume. The substrate heating uniformity was achieved by properly shaping the heater.

The gas-dynamic parameters in the flowthrough type reactor were chosen by matching consumables to the flux velocity, number of yielded reaction products, pumping system throughput. It was of especial importance to match those parameters in the diffusion region of the precipitation conditions where the deposition rate was controlled, mainly, by the vapor-gas velocity and dependent weakly on the temperature of the process.

The data represented show that in the range of parameters studied the vapour-gas flow is laminar and have a viscous nature of the flow, convective currents are absent. This flow provides uniform delivery of reagents to the surface to be coated and virtually the same growth rate of the layer at all points of the base.

Fig. 1 shows the morphology of condensates. According to the figure, the morphology of the surface is characterized by grapple-scraped globules.

Investigation of elements distribution in samples from the center of the substrate in the direction of the coating is performed on a microanalyzer - a raster microscope REMMA-200. $\mathrm{X}$-ray spectral studies used standards for pure substances $(\mathrm{Fe}, \mathrm{Cr}, \mathrm{Ni})$. As can be seen from Fig. 2, at a distance from 0 to $100 \mu \mathrm{m}$, the distribution of elements is uniform, this indicates that when austenitic steel is heated, no significant change in properties occurs. At distances from 100 to $225 \mu \mathrm{m}$, the distribution of elements varies by diffusion of boron and carbon, which characterizes the formation of mixed phases of boron, carbon with iron, chromium and nickel.

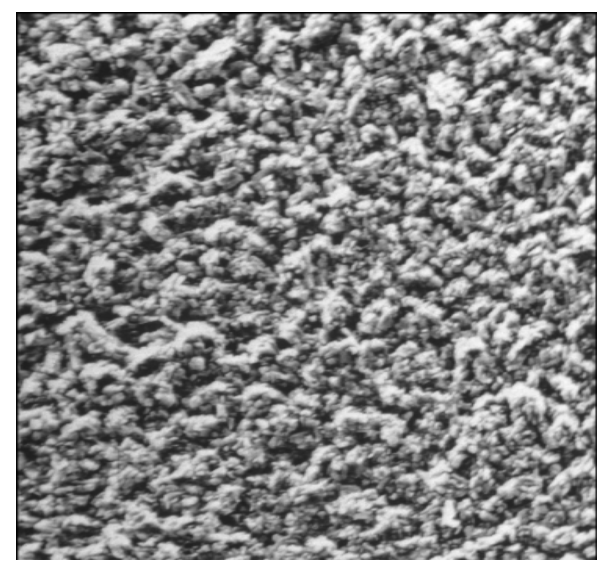

Fig. 1. Morphology of the surface of the coatings based of carbide boron, $\times 650$

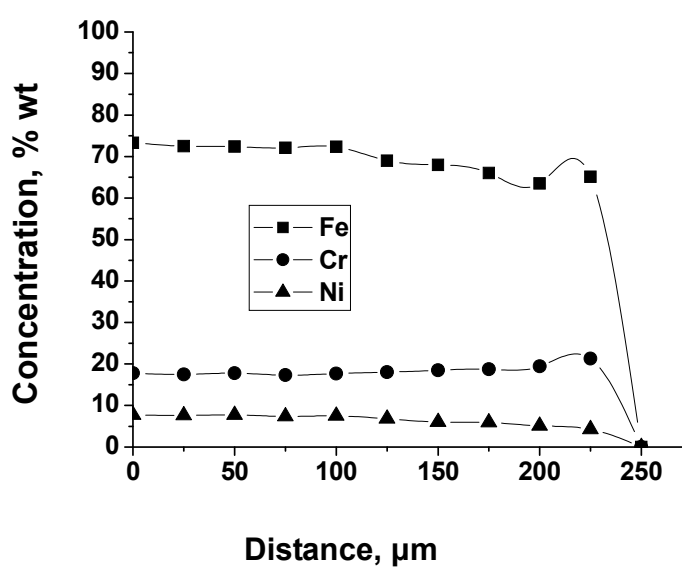

Fig. 2. Distribution of main elements in austenitic steel with coating

Diffractometric studies of samples, Fig. 3, were carried out on X-ray diffractometer DRON-4-07 in copper $\mathrm{Cu} K_{\alpha}$ radiation using $\mathrm{Ni}$ and $\mathrm{Fe}$ of selectively absorbent $\beta$-filter. The diffracted radiation was recorded by a scintillation detector. The shooting of the diffractograms was done in step-by-step mode.

As a result of the phase analysis of the samples, a phase was detected: iron boride $\mathrm{Fe}_{2} \mathrm{~B}$. The coating contains a texture (100), that is, the grain of $\mathrm{Fe}_{2} \mathrm{~B}$ iron boride is mainly oriented crystallographic planes $\{100\}$ parallel to the surface of the sample. Fe- $\gamma$ austenite and $\mathrm{Fe}_{7} \mathrm{C}_{3}$ iron carbide were also detected. The lining (steel 
$\mathrm{X} 18 \mathrm{H} 10 \mathrm{~T})$ is textured, the grains are mainly oriented with the crystallographic planes $\{110\}$ in parallel with the surface of the sample.

Metal grit samples were made and their microhardness was measured with a microhardness measurement unit PMT-3 (Nm -

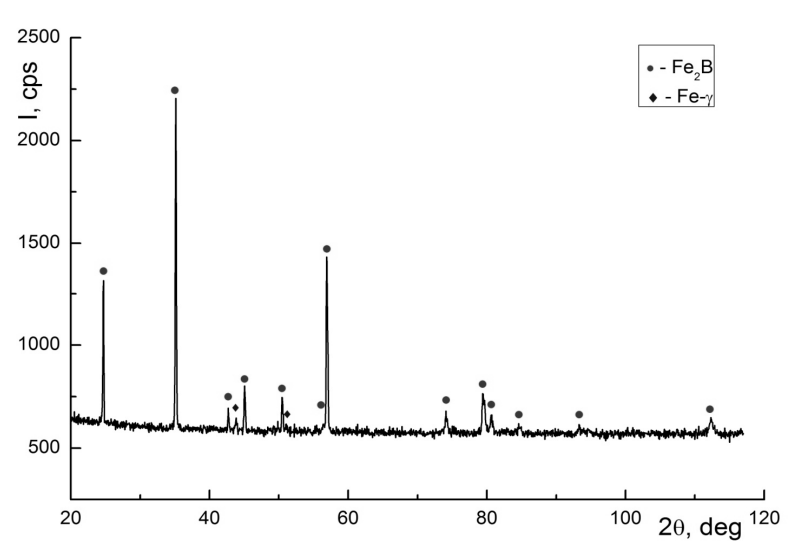

Fig. 3. Diffractometric study of samples $\mathrm{kg} / \mathrm{mm}^{2}$ - load 200 grams, from the center of the sample to the edge with a step of 30 microns), Table. As can be seen from the table, the microhardness from the center of the substrate to the side of the coating is double increased.

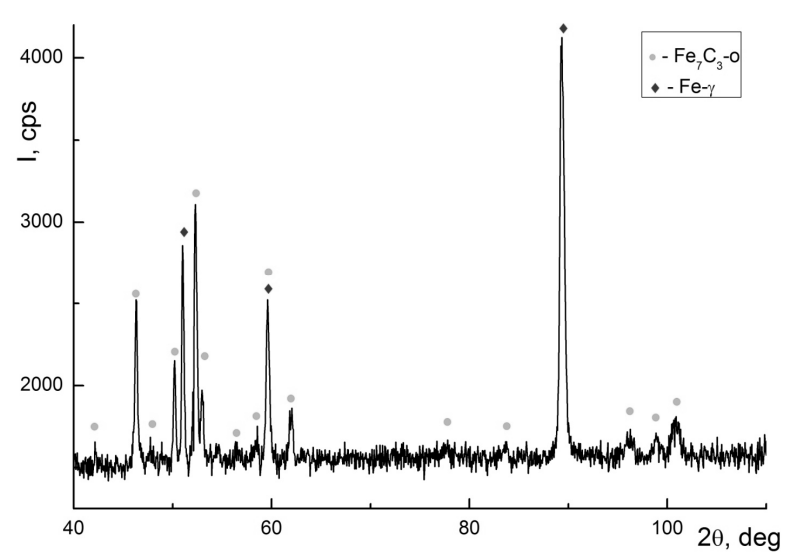

Table.

\begin{tabular}{|c|c|c|c|c|c|c|c|c|}
\hline $\begin{array}{l}\text { Distance from } \\
\text { center to tip of } \\
\text { sample, } \mu \mathrm{m}\end{array}$ & 50 & 75 & 100 & 125 & 150 & 175 & 200 & 225 \\
\hline $\begin{array}{l}\text { The value of } \\
\text { microhardness, } \\
\mathrm{H}_{\mathrm{m},} \mathrm{kg} / \mathrm{mm}^{2}\end{array}$ & 357 & 379 & 405 & 458 & 580 & 700 & 810 & 700 \\
\hline
\end{tabular}

Destruction of samples under the influence of cavitation was studied on the installation of ultrasound cavitation. The cavitation zone was formed between the end of the emitter, which is connected with an ultrasonic generator of UZG-3 0.4 type, and the surface of the test specimen installed in water having the temperature of $293 \mathrm{~K}$. The radiator is a concentrator of ultrasonic vibrations of the exponential profile. Experimental results on the determination of the size of erosive destruction are shown in Fig. 4.

For comparison, the kinetic curve of the destruction of the standard A18H10T austenitic steel and a boron carbide-based sample is given. As can be seen from Fig. 4 under the same test conditions, the nature of the kinetic curves is different. A sample with a carbide-boron coating is 2.5 times less cavitation wear than austenitic steel.

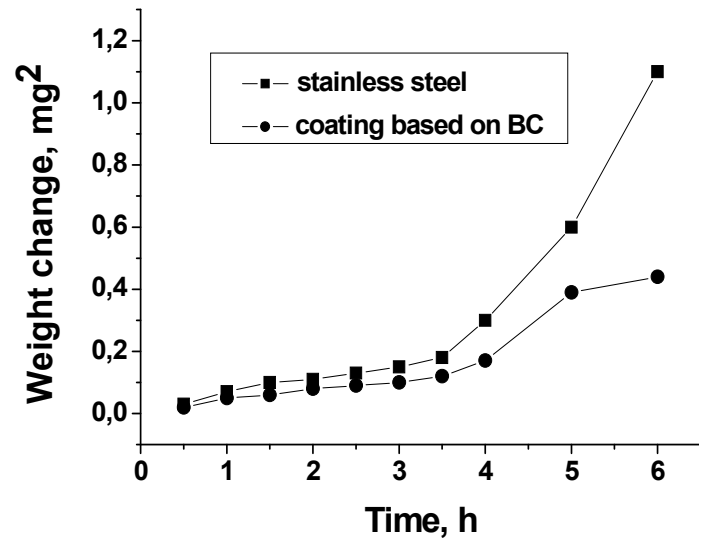

Fig. 4. Cavitational wear of a specimen of austenitic steel and that with coating 


\section{CONCLUSIONS}

The process of gas phase deposition of coatings on the basis of boron carbide on austenitic steel has been worked out, in which the surface of the coating is characterized by grapple-sculpt globules. Experimental results on the determination of the amount of erosive destruction have shown that the sample with a boron carbide coating is 2.5 times less cavitation wear than austenitic steel.

\title{
Газофазне осадження кавітаційностійкого покриття на основі карбіду бору
}

\section{О.Ю. Журавльов, О.В. Шиян, Б.М. Широков}

Національний науковий центр «Харківський фізико-технічний інститут» вул. Академічна, 1, Харків, 61108, Україна, shirokov@kipt.kharkov.иа

\begin{abstract}
Надійність і економічність експлуатачії АЕС будь-якого типу в значній мірі залежать від надійної роботи системи ї̈ трубопроводів. 3 літературних джерел показано, що найбільш небезпечна зона, с точки зору ерозійного зносу, - це заворот трубопроводу. Розв'язання проблеми ерозійного зносу зони заворотів трубопроводів можливе шляхом газофазного осадження захисних покриттів на основі карбіду бору, які загальмують кавітаційні процеси зносу. У даній роботі представлені результати досліджень отримання кавітайійностійкого покриття на основі карбіду бору водневим відновленням трихлористого бору $\mathrm{BCl}_{3} i$ толуолу $\mathrm{C}_{7} \mathrm{H}_{8}$. Отримання карбіду бору здійснювали на установиі з горизонтальною реакційною камерою проточного типу. Принцип іï дї̈ складається в пропусканні через реакиійну камеру парогазового потоку реагентів, що вступають у хімічну реакцію на поверхні розігрітої підкладки, розмішеної усередині реакиійноі камери. Твердофазні продукти реакиії утворюють на поверхні підкладки наростаючий шар конденсату, а газоподібні продукти видаляються з реакиійної камери і нейтралізуються. Як реагенти було обрано трихлористий бор $\mathrm{BCl}_{3}$ та толуол $\mathrm{C}_{7} \mathrm{H}_{8}$. Як газ-носій $і$ активатор був водень $\mathrm{H}_{2}$. Осадження здійснювалося на підкладку з аустенітної сталі. Наведено морфологію конденсатів. Показано, що морфологія поверхні росту характеризується міцнозчепленими глобулами. Рентгенівські спектральні дослідження показали, що розподіл елементів є рівномірним, що вказує на те, щсо при нагріві аустенітної сталі істотних змін властивостей не відбувається. Дифрактометричні дослідження показали, що покриття містить зерно бориду заліза $\mathrm{Fe}_{2} \mathrm{~B}$ та карбіду заліза $\mathrm{Fe}_{7} \mathrm{C}_{3}$. Вимірювання мікротвердості показали, що від иентру підкладки до сторони покриття вона збільшується вдвічі. Руйнування зразків при впливі кавітації вивчалося на установиі ультразвукової кавітації. Кавітаційна зона формувалася між торием випромінювача, який з'єднаний з ультразвуковим генератором типу УЗГ-3 0.4. Випромінювач є концентратором ультразвукових коливань експоненціального профілю. Для порівняння наведено кінетичну криву руйнування стандартної аустенітної сталі А18Н10Т та зразка на основі карбіду бору. У тих самих умовах тестування характер кінетичних кривих відрізняється. Зразки з покриттям з твердосплавного матеріалу мають в 2.5 рази менше кавітаиійного зносу, ніж аустенітна сталь.
\end{abstract}

Ключові слова: газофазне осадження, карбід бору, кавітаційний знос 


\title{
Газофазное осаждение кавитационностойкого покрытия на основе карбида бора
}

\author{
А.Ю. Журавлев, А.В. Шиян, Б.М. Широков
}

Национальный научный изентр «Харьковский физико-технический институт» ул. Академическая, 1, Харьков,61108, Украина, shirokov@kipt.kharkov.ua

\begin{abstract}
Надежность и экономичность эксплуатации АЭС любого типа в значительной степени зависят от надежной работы системы ее трубопроводов. Из литературных источников показано, что наиболее опасная зона, с точки зрения эрозионного износа, - это поворот трубопровода. Решение проблемы эрозионного износа зоны поворотов трубопроводов возможно путем газофазного осаждения защитных покрытий на основе карбида бора, которые затормозят кавитационные прочессы износа. В данной работе представлены результаты исследований получения кавитационностойкого покрытия на основе карбида бора водородным восстановлением треххлористого бора $B C l_{3}$ и толуола $C_{7} H_{8}$. Получение карбида бора осуществляли на установке с горизонтальной реакционной камерой проточного типа. Принци ее действия состоит в пропускании через реакциионную камеру парогазового потока реагентов, вступающих в химическую реакцию на поверхности разогретой подложки, размещенной внутри реакционной камеры. Твердофазные продукты реакции образуют на поверхности подложки нарастаюший слой конденсата, а газообразные продукты удаляются из реакиионной камеры и нейтрализуются. В качестве реагентов был избран треххлористый бор $B_{3}$ и толуол $C_{7} H_{8}$. Несущзим газом и активатором являлся водород $H_{2}$. Осаждение осуществлялось на подложку из аустенитной стали. Приведена морфология конденсатов. Показано, что морфология поверхности роста характеризуется крепко-сцепленными глобулами. Рентгеновские спектральные исследования показали, что распределение элементов является равномерным, что указывает на то, что при нагреве аустенитной стали, существенных изменений свойств не происходит. Дифрактометричные исследования показали, что покрытие содержит зерно борида железа $\mathrm{Fe}_{2} \mathrm{~B}$ и карбида железа $\mathrm{Fe}_{7} \mathrm{C}_{3}$. Измерения микротвердости показали, что от центра подложки к стороне покрытия она увеличивается вдвое. Разрушение образиов под влиянием кавитации изучалось на установке ультразвуковой кавитации. Кавитационная зона образована между концом излучателя, который соединен с ультразвуковым генератором типа УЗГ-3 0.4, а поверхность испытуемого образиа установлена в воде с температурой $293 \mathrm{~K}$. Для сравнения приведень кинетические кривые разрушения стандартной аустенитной стали А18Н10Т и образца на основе карбида бора. В тех же условиях тестирования характер кинетических кривых отличается. Образиы с покрытием из твердосплавного материала имеют в 2.5 раза меньше кавитационный износ, чем аустенитная сталь.
\end{abstract}

Ключевые слова: газофазное осаждение, карбида бора, кавитационный износ

\section{REFERENCES}

1. Chudakov M.V. Ph.D. (Technical sci.) Thesis. (St. Petersburg, 2005). [in Russian].

2. Kastner W., Erve M., Henzel N., Stellwag B. Erosion corrosion in power plant piping systems-calculation code for predicting wall thinning. International Atomic Energy Agency, Vienna (Austria). International Working Group on Reliability of Reactor Pressure Components. 1990. 22(11): 49.

3. Polishchuk S.M., Manuz A.A. Analysis of the research of erosion-corrosion wear of NPP pipelines. EasternEuropean Journal of Enterprise Technologies. 2007. 1/3(25): 3. [in Russian]. 